\title{
Anti-AGS-8 Monoclonal Antibody AGS-8M4
}

National Cancer Institute

\section{Source}

National Cancer Institute. Anti-AGS-8 Monoclonal Antibody AGS-8M4. NCI Thesaurus.

Code C82686.

A humanized monoclonal antibody directed ag ainst the activator of g-proteins signaling (AGS) cell surface protein AGS-8 with potential antineoplastic activity. Anti-AGS-8 monoclonal antibody AGS-8M4 selectively binds to AGS-8, triggering complementdependent cell lysis and antibody-dependent cell-mediated cytotoxicity in tumor cells expressing AGS-8. While normally expressed at low levels in the heart in response to ischemia, AGS- 8 has been found to be expressed in more than $70 \%$ of ovarian neoplasms. 